\title{
Vertrouwen in onderzoek naar verkiezingen : Enkele opmerkingen over kiezersonderzoek en het beoordelen van verkiezingen.
}

Citation for published version (APA):

Schmeets, J. J. G. (2009). Vertrouwen in onderzoek naar verkiezingen : Enkele opmerkingen over kiezersonderzoek en het beoordelen van verkiezingen. Maastricht University. https://doi.org/10.26481/spe.20090306hs

Document status and date:

Published: 06/03/2009

DOI:

10.26481/spe.20090306hs

Document Version:

Publisher's PDF, also known as Version of record

Please check the document version of this publication:

- A submitted manuscript is the version of the article upon submission and before peer-review. There can be important differences between the submitted version and the official published version of record.

People interested in the research are advised to contact the author for the final version of the publication, or visit the DOI to the publisher's website.

- The final author version and the galley proof are versions of the publication after peer review.

- The final published version features the final layout of the paper including the volume, issue and page numbers.

Link to publication

\footnotetext{
General rights rights.

- You may freely distribute the URL identifying the publication in the public portal. please follow below link for the End User Agreement:

www.umlib.nl/taverne-license

Take down policy

If you believe that this document breaches copyright please contact us at:

repository@maastrichtuniversity.nl

providing details and we will investigate your claim.
}

Copyright and moral rights for the publications made accessible in the public portal are retained by the authors and/or other copyright owners and it is a condition of accessing publications that users recognise and abide by the legal requirements associated with these

- Users may download and print one copy of any publication from the public portal for the purpose of private study or research.

- You may not further distribute the material or use it for any profit-making activity or commercial gain

If the publication is distributed under the terms of Article 25fa of the Dutch Copyright Act, indicated by the "Taverne" license above, 


\section{Vertrouwen in onderzoek naar verkiezingen}

Enkele opmerkingen over kiezersonderzoek en het beoordelen van verkiezingen

IntreeRede

In verkorte en vrije vorm uitgesproken bij de aanvaarding van het ambt van bijzonder hoogleraar 'Sociale Statistiek, in het bijzonder de empirische bestudering van sociale samenhang' aan de faculteit van Cultuur- en Maatschappijwetenschappen van de Universiteit Maastricht

Op vrijdag 6 maart

door

J.J.G. (Hans) Schmeets 
Mijnheer de Rector Magnificus, Collega's, familie, vrienden en bekenden, Zeer gewaardeerde toehoorders,

\section{Inleiding}

Het hart van de democratie wordt gevormd door verkiezingen. Dan is het moment aangebroken dat de kiezer zelf aan het woord is. Vertrouwen is een cruciale en centrale factor bij verkiezingen. De kiezer moet er op kunnen rekenen dat zijn of haar stem even zwaar meetelt bij het bepalen van de stembusuitslag en dat de privacy gewaarborgd is bij het uitbrengen van de stem. Bovendien zal de kiezer vertrouwen moeten hebben in de transparantie van het verkiezingsproces, zodat de uitgebrachte stemmen en het tellen van de stemmen valt te controleren. Zijn de verkiezingen in ons land wel transparant? Is de privacy wel gewaarborgd?

Ik zal vandaag met $u$ enkele aspecten bespreken die naar voren komen bij onderzoek naar verkiezingen. Dit zal ik doen door deze van twee kanten te bekijken: het onderzoek naar opvattingen van het electoraat én het onderzoek naar de beoordeling van verkiezingen. Ik ga u vertellen hoe dit onderzoek is opgezet en uitgevoerd, en ik zal ingaan op het vertrouwen in de onderzoeksbevindingen. Na Nederland, neem ik u mee Europa in: naar de Balkan, naar Rusland, Wit-Rusland en de Oekraïne, naar de Kaukasus, en verder naar Kazachstan, Tadzjikistan en Kirgizië. Ik ben daar de afgelopen dertien jaar vaak naar toe gegaan om de bevindingen van de internationale verkiezingswaarnemers te analyseren.

Onderzoek naar verkiezingen vormt een onderdeel van mijn leerstoelopdracht: de sociale statistiek en in het bijzonder de empirische bestudering van sociale samenhang. In het derde deel van mijn betoog ga ik in op het bestuderen van sociale samenhang aan de hand van databestanden waarin registraties en grootschalige enquêteonderzoeken zijn samengeknoopt.

\section{Vertrouwen in sociale statistieken: het kiezersonderzoek}

\section{Sociale Statistieken}

Laat ik beginnen met het kiezersonderzoek. Dergelijk onderzoek staat in het teken van opvattingen en stemgedrag van het electoraat. Daarbij gaat het uiteindelijk om de achtergronden van de stemkeuze: wie stemt er, op welke partij en waarom? Kunnen we vertrouwen hebben in dergelijk onderzoek onder het electoraat, en in bredere zin kunnen we de sociale statistieken vertrouwen? En hoe kunnen we dat vaststellen?

Om deze vragen te beantwoorden, geef ik $u$ een kijkje in de keuken van het Centraal Bureau voor de Statistiek, waar de ingrediënten klaarstaan waarmee de sociale statistieken worden bereid. Velen van u kennen deze ingrediënten wel: de steekproef, de vragenlijst, het veldwerk, de wijze van gegevensverzameling, de respons, en het corrigeren van de selectiviteit in de respons.

Het verzamelen van gegevens uit enquêtes gaat ongeveer als volgt. Op basis van de Gemeentelijke Basisadministraties worden zogeheten steekproefkaders 
gemaakt waaruit de steekproeven voor de enquêtes worden getrokken. Deze steekproef is een verkleinde afspiegeling van de afgebakende bevolkingsgroep.

Dat is de theorie. De praktijk is weerbarstiger. Niet iedereen die geselecteerd is, is bereid om aan het onderzoek mee te doen. Er is nog een probleem. De groep die meedoet aan het onderzoek en de groep die dat weigert verschillen in tal van opzichten van elkaar. Zo is de deelname op het platteland doorgaans groter dan in de steden. Door te corrigeren op basis van sociale achtergrondkenmerken hopen we dat de inhoudelijke kenmerken, zoals politieke opvattingen, adequaat worden bijgesteld.

Dat lukt lang niet altijd. We weten niet goed hoe groot de vertekening is als gevolg van de selectiviteit in de non-respons. Als iedereen zou meedoen, is er geen vertekening. Het optimaliseren van de respons is zodoende de panacee om deze vertekening te bestrijden.

Hoe is het gesteld met de respons en de vertekening binnen de sociale statistiek? In een kiezersonderzoek gaat het om de meningen van het hele electoraat, en niet alleen van het politiek geëngageerde segment. De meningen van de stemgerechtigden zonder politieke interesse en van de niet-stemmers mogen daarin niet ontbreken. Het is bekend dat het uiterst lastig is om deze personen erbij te betrekken. Ze zijn vaak op voorhand ervan overtuigd dat ze niet veel in te brengen hebben en de vragen niet adequaat kunnen beantwoorden.

Voor het recente kiezersonderzoek is daarom een specifieke brief opgesteld om ook deze groep te overtuigen deel te nemen aan het vraaggesprek. In die brief is vermeld dat het vraaggesprek niet alleen over politieke onderwerpen gaat, maar vooral ook over brede maatschappelijke onderwerpen, zoals de aftrek van de hypotheekrente.

Daarnaast is nog een specifieke maatregel genomen om de respons te optimaliseren. In de brief is een postzegelboekje ter waarde van 4 euro bijgesloten. Dat was een weloverwogen stap. Een experiment had ons geleerd dat het geven van een attentie in de vorm van postzegels de respons substantieel met 8 procentpunten - kon vergroten. Deze attenties werkten bovendien bijzonder goed in Amsterdam, Rotterdam en Den Haag. Ze hadden echter geen effect op de respons onder de niet-westerse allochtonen. En als derde maatregel zijn de personen die weigerden om te participeren of niet werden bereikt, herbenaderd om mee te doen.

\section{Effecten benaderingsstrategie: drie graadmeters}

Welk effect hebben deze inspanningen gehad op de respons en de vertekening van het Nationaal Kiezersonderzoek? De eerste graadmeter is het responspercentage. In een politieke studie, zoals het Nationaal Kiezersonderzoek, willen we niet alleen weten wat de kiezers voorafgaande aan de verkiezingen van plan waren te gaan stemmen, maar willen we ook na de verkiezingen het stemgedrag vaststellen. Dus moeten we twee gesprekken met dezelfde personen voeren.

Aan het eerste gesprek nam 67 procent deel. De personen die thuis niet werden bereikt en de weigeraars zijn herbenaderd met een verkorte schriftelijke vragenlijst of per telefoon. Dit levert nog 5 procent extra respons op. Daarmee 
komt de respons op 72 procent. Uiteindelijk hebben ruim 2800 personen aan het eerste gesprek meegedaan. Deze respondenten zijn vervolgens verzocht om aan het vervolgonderzoek, kort na de verkiezingsdag, mee te doen. Er blijven ruim 2500 personen over die aan beide gesprekken hebben meegedaan. Nog nooit in de geschiedenis van het Nationaal Kiezersonderzoek vanaf 1971 is de deelname met een respons van 72 procent na het eerste en 64 procent na het tweede gesprek zo groot. Dat is dus positief.

De verdeling van de respons over de bevolkingsgroepen is de tweede graadmeter. We constateren geen verschillen in respons tussen mannen en vrouwen, tussen leeftijdsgroepen en naar stedelijkheid. Wel is de respons van de niet-westerse allochtonen lager dan van de autochtonen. Dit zal mede veroorzaakt worden door het effect op de respons van de postzegels in de aanschrijfbrief.

De derde graadmeter is in welke mate het resultaat van het Nationaal Kiezersonderzoek overeenstemt met de stembusuitslag. Het blijkt dat de kleine NKO-steekproef nagenoeg perfect de stembusuitslag weergeeft (zie Tabel 1). Slechts de SP is met één zetel oververtegenwoordigd, ten koste van de PVV. Blijkbaar kunnen we met een klein onderzoek en een goede respons de kerninformatie over kiezersgedrag - de partijkeuze - adequaat weergeven.

Nemen we - ter vergelijking - de opiniepeilingen als maatstaf, dan valt op dat in de peilingen 'De Stemming', 'Peil.NL', en 'De Politieke Barometer' zonder uitzondering de electorale kiezersplank flink is misgeslagen. De uitslag volgens 'De Stemming' werd reeds kort voor sluiting van de stemlokalen uitgezonden door RTL4 dat de kijkers liet weten dat de SP met 32 zetels de tweede partij was geworden. Uiteindelijk zou de SP 25 zetels krijgen.

Enkele minuten later zag dat beeld er geheel anders uit toen de 'Politieke Barometer' en 'Peil.NL' verschenen. Nu kwam de PvdA als een sterke tweede partij naar voren met respectievelijk 37 en 38 zetels. De PVV kreeg in beide peilingen maar 4 respectievelijk 5 zetels.

Tabel 1. Zetelverdeling volgens opiniebureaus, het NKO en stembusuitslag, 2211-2006.

\begin{tabular}{|l|l|l|l|l|l|}
\hline & $\begin{array}{l}\text { Politieke } \\
\text { barometer }\end{array}$ & Peil.NL & $\begin{array}{l}\text { De } \\
\text { Stemming }\end{array}$ & $\begin{array}{l}\text { Nationaal Kiezers- } \\
\text { onderzoek }\end{array}$ & Stembusuitslag \\
\hline CDA & 41 & 42 & 41 & 41 & 41 \\
\hline PvdA & 37 & 38 & 31 & 33 & 33 \\
\hline VVD & 23 & 22 & 21 & 22 & 22 \\
\hline SP & 23 & 23 & 32 & 26 & 25 \\
\hline PVV & 4 & 5 & 6 & 8 & 9 \\
\hline GroenLinks & 7 & 8 & 5 & 7 & 7 \\
\hline D66 & 3 & 2 & 1 & 3 & 3 \\
\hline CU & 6 & 6 & 8 & 6 & 6 \\
\hline SGP & 2 & 2 & 3 & 2 & 2 \\
\hline P vd Dieren & 2 & 1 & 2 & 2 & 2 \\
\hline Een NL & 1 & 1 & 0 & 0 & 0 \\
\hline LPF & 1 & 0 & 0 & 0 & 0 \\
\hline
\end{tabular}


$\mathrm{Nu}$ zult u zich afvragen waarom die voorspellingen zo verschillen en niet sporen met de uitslag. Ten eerste maken de opiniebureaus veelal gebruik van een groep personen die zich vrijwillig hebben gemeld om aan de onderzoeken mee te doen. Een selectie uit die groep wordt benaderd en kan meedoen en sommigen doen heel vaak mee. Maar velen niet. Het responscijfer is niet af te leiden, evenmin wat de verdeling is van deze respons over de bevolkingsgroepen. Dat dergelijke bevindingen - gebaseerd op de zogenoemde ACCESS-panels - met een korreltje zout genomen moeten worden, staat buiten kijf. Het is dan ook allerminst een verrassing dat de peilingen van afgelopen week over de opmars van de PVV zo verschillen.

Het Nationaal Kiezersonderzoek levert wel een adequate afspiegeling van de partijpolitieke verhoudingen op. Toch is er nog een probleem. Dat is de opkomst. Zo'n 80 procent had gestemd, terwijl volgens het kiezersonderzoek 93 procent naar de stembus zou zijn gegaan. Deze vertekening van 13 procent is fors, maar verklaarbaar.

Ten eerste zal een deel van de potentiële niet-stemmers uiteindelijk toch zijn gaan stemmen. Als gevolg van het interview, waarin talrijke politieke onderwerpen de revue passeren, raken veel potentiële niet-stemmers gemotiveerd om toch op de verkiezingsdag te stemmen. Dit is het stimuluseffect. Het gevolg van dit stimuluseffect is dat in het onderzoek de stemmers zijn oververtegenwoordigd, en de niet-stemmers ondervertegenwoordigd. Dit stimuluseffect is echter niet zo groot dat het verklaren kan dat van de 20 procent geselecteerde niet-stemmers maar liefst 13 procent toch is gaan stemmen. $\mathrm{Er}$ speelt meer dan alleen het stimuluseffect.

Er zijn twee alternatieve verklaringen voor de overrapportage van het opkomstcijfer. De eerste is de selectiviteit van de non-respons: vooral de stemmers participeren in het onderzoek. De tweede is sociale wenselijkheid: de deelnemers aan het onderzoek willen achteraf liever niet toegeven dat ze niet hebben gestemd. Er zijn dus zeker drie verklaringen voor de overrapportage: het stimuluseffect, de selectiviteit van de non-respons en de sociale wenselijkheid.

Om meer grip te krijgen op deze drie verklaringsbronnen is in twee andere CBSonderzoeken de vraag naar het stemgedrag opgenomen. Dit gebeurde eveneens vlak na de verkiezingsdag van 22 november 2006, in zowel het Permanent Onderzoek Leefsituatie als in de Enquête Beroepsbevolking. Deze personen hadden dus geen gesprek over de politiek vóór de verkiezingen, en zijn op deze wijze niet gemotiveerd of gestimuleerd om te gaan stemmen. De opkomst in beide onderzoeken lag op 88 procent, 8 procent hoger dan het officiële opkomstcijfer.

Dit betekent dat de overrapportage van 13 procent in het Nationaal Kiezersonderzoek voor 5 procentpunten voor rekening komt van het stimuluseffect. De overige 8 procentpunten schrijven we toe aan een combinatie van sociale wenselijkheid en selectieve non-respons. Uit ander onderzoek blijkt dat een kwart - dus 2 procent - veroorzaakt wordt door sociale wenselijkheid, en driekwart - dus 6 procent - door selectiviteit.

Stel dat dit klopt, dan hebben we dus niet 20 procent niet-stemmers in de steekproeven, maar 14 procent. Op basis van deze kennis zouden we in het vervolg bij het samenstellen van sociale statistieken deze 14 procent niet- 
stemmers iets meer kunnen meetellen, ten koste van de stemmers. Dit heeft vooral gevolgen voor de kenmerken die samenhangen met de opkomst, zoals de werkloosheid. De werkloosheid zal toenemen aangezien de niet-stemmers beduidend vaker werkloos zijn dan de stemmers. Een ander voorbeeld is het vaststellen van het aantal personen dat vrijwilligerswerk verricht. Dit aantal zal afnemen omdat stemmers zich vaker als vrijwilliger inzetten dan niet-stemmers.

Ik kom nu tot een eindoordeel over het vertrouwen in de sociale statistiek op basis van het recente Nationaal Kiezersonderzoek. Het beeld daarover is verdeeld. Het feit dat het onderzoek de bijna perfecte afspiegeling is van de stembusuitslag, genereert veel vertrouwen in het grondmateriaal. Ook de hoge respons, en de geringe selectiviteit van de non-respons bij de reguliere sociale achtergrondkenmerken scheppen een stevige vertrouwensbasis. Daar tegenover staat dat de ondervertegenwoordiging van de niet-stemmers enigszins problematisch is.

Vertrouwen in sociale statistieken: jazeker, maar het kan altijd beter. De respons zal aandacht blijven vragen. Niet alleen de hoogte ervan, maar ook de selectiviteit. Ik zal daar binnen de opdracht van de leerstoel aandacht aan geven.

\section{Het oordeel over verkiezingen}

\section{Verkiezingswaarnemingsmissies}

Hoeveel vertrouwen hebben anderen eigenlijk in onze verkiezingen? De Organisatie voor Veiligheid en Samenwerking in Europa - de OVSE - heeft zich gebogen over de stemprocedures. Een van de hoofdtaken van de OVSE is om de verkiezingen van de 56 lidstaten te beoordelen aan de hand van criteria die in 1990 in de zogenoemde Kopenhagen-bepalingen zijn vastgelegd. Nederland heeft zich als één van die 56 OVSE-landen hieraan gecommitteerd.

Op 12 maart 2007 verscheen het OVSE-rapport. Geconstateerd werd dat de Nederlandse verkiezingen over het algemeen voldeden aan de internationale maatstaven. Kritisch was de OVSE over het stemmen met stemcomputers. Zij plaatste kanttekeningen bij de beveiliging van de stemcomputers en de onmogelijkheid om de stemkeuze met een 'papieren' uitdraai van de stemmen te controleren.

De OVSE constateerde nog meer eigenaardigheden bij de Nederlandse verkiezingen. Van het recht om te stemmen voor iemand anders - het stemmen met volmacht - wordt in Nederland massaal gebruik gemaakt. Volgens hun schattingen stemt tussen 10 tot 20 procent van de kiezers niet zelf, maar laat dat door iemand anders doen. In de meeste lidstaten van de OVSE is dergelijke 'proxy voting' verboden. Daarmee moet worden voorkómen dat er onregelmatigheden plaatsvinden, zoals het opkopen van stemmen. Het gevaar ligt immers op de loer dat een kiezer zijn of haar stembiljet niet geheel uit vrije wil aan iemand anders geeft. Dergelijke praktijken druisen in tegen de principes dat elke kiezer mag meedoen met de verkiezingen, dat elke stem in gelijke mate meetelt en dat stemmen op een vrije manier gebeurt, zonder intimidatie en dwang. 
Het OVSE-onderzoek in Nederland gebeurde door een zogenoemde Election Assessment Mission. Acht experts hebben enkele weken de verkiezingen geobserveerd. Steeds vaker gebruikt de OVSE een kleine expertgroep, met name voor het beoordelen van 'oude democratieën', waaronder Nederland en recentelijk de Verenigde Staten.

Voor het beoordelen van andere verkiezingen maakt de OVSE doorgaans gebruik van een verkiezingswaarnemingsmissie, waarbij massaal internationale waarnemers worden ingezet. Sinds 1996 is dat zo'n honderd keer gebeurd. Het aantal waarnemers varieert meestal van zo'n 150 tot 200 in kleine missies tot wel 1400 in de Oekraïne.

Deze waarnemers bezoeken de stemlokalen en noteren hun bevindingen op een vragenlijst. Rond drie uur in de middag na de verkiezingen geeft de OVSE een voorlopig oordeel. Het definitieve rapport verschijnt zo'n twee maanden later.

Hoe vindt de dataverzameling plaats? De waarnemers gaan in tweetallen op pad, meestal vergezeld van een tolk, en observeren de procedures voordat het stemlokaal de deuren opent voor de kiezers. Hun bevindingen noteren zij in een vragenlijst. Vervolgens bezoeken ze zo'n tien stemlokalen. Per observatie vullen zij een vragenlijst in over de omstandigheden en procedures bij het stemmen. De derde fase is die van het tellen van de stemmen. Wederom wordt een stemlokaal geselecteerd en geobserveerd. Ten slotte worden de uitkomsten van alle tellingen in regionale tabuleercentra verwerkt. Ook daar zijn de waarnemers bij aanwezig. Per formulier worden zo'n 30 tot 60 vragen gesteld. Dan zijn er nog aparte formulieren voor aanvullende schriftelijke opmerkingen en commentaren.

Al deze formulieren worden meestal per fax verstuurd, waarna de gegevens worden verwerkt door de lokale personen die de data-invoer verzorgen. Om een indruk te geven: in de Oekraïne waren dat er zo'n 60, verdeeld over twee ploegen van elk 30 personen: waaronder 5 Svletjana's, 4 Tatjana's en 4 Vadims. Zij waren 12 uur bezig om zo'n 8 kilometer aan faxpapier te verwerken.

Het oordeel over de verkiezingsdag wordt cijfermatig in beeld gebracht en ingekleurd met de honderden pagina's commentaar. Daarin wordt verfijnd uit de doeken gedaan waarom men bijvoorbeeld heeft opgegeven dat er intimidatie plaatsvindt, dat er allerlei personen in het stemlokaal aanwezig zijn geweest die daar niets te zoeken hadden, zoals politieagenten en onbevoegde partijfunctionarissen. Ook over de privacy wordt gerapporteerd, zoals het zogenoemde family voting waarbij man en vrouw samen in het stemhokje de stemkeuze bepalen. Tot slot wordt per stemlokaal een eindoordeel gegeven over het verkiezingsproces. Is dat heel goed, goed, slecht of heel slecht? Dit resultaat vat als het ware alle specifieke problemen en onregelmatigheden samen. Dat weten we op basis van onderzoek over de correlaties tussen het eindoordeel en de antwoorden op specifieke vragen over de omstandigheden en procedures.

Ik geef $u$ enkele indrukken van de onregelmatigheden die waarnemers noteren. In Bosnië zijn er altijd problemen met de kiezerslijsten. Veel kiezers kunnen niet stemmen omdat ze niet op een kiezerslijst staan, of door fouten in de lijsten. Dat was al zo in 1996 vlak na het Dayton-akkoord, en in 2006 was dat nog steeds het geval. In Kazachstan zien veel waarnemers nauwelijks kiezers gedurende hun verblijf in de stemlokalen. Ze zijn dan ook stomverbaasd als achteraf blijkt dat in de meeste stemlokalen meer dan 95 procent heeft gestemd en dan nog wel op 
dezelfde persoon of partij. In Wit-Rusland worden veel waarnemers bij het tellen van de stemmen op afstand gehouden zodat ze nauwelijks kunnen waarnemen. Rusland maakt het inmiddels nog bonter. De waarnemers werden bij de voorgaande parlements- en presidentsverkiezingen niet eens toegelaten, een unicum in de geschiedenis van de OVSE. Dat dit indruist tegen de gemaakte internationale afspraken, spreekt voor zich.

Als je als waarnemer naar een land wilt waar allerlei fraude openlijk wordt gedemonstreerd, dan hoef je helemaal niet ver te reizen. In het Albanese deel van Macedonië is een redelijke kans dat je stembussen vindt die zijn volgepropt met stembiljetten of zelfs helemaal geen stembussen, dezelfde handtekeningen op de kiezerslijsten, talrijke onbevoegde personen in en rondom de stemlokalen en veel intimidatie van kiezers. De waarnemers komen daags na de verkiezingen bijeen in de de-briefing. De teams in het etnisch-Macedonische deel kunnen nauwelijks de verhalen geloven van hun collega's in de etnisch-Albanese gebieden.

Analoog aan de sociale statistieken van het CBS, kunnen we ons afvragen of we vertrouwen kunnen hebben in deze OVSE-verklaringen. Worden de bevindingen van de waarnemers correct weergegeven? En hoe zit het met de waarnemers zelf: zijn zij wel te vertrouwen?

Tot 2003 waren de waarnemers vooral afkomstig uit westerse landen. Uit de voormalige Oostbloklanden namen nauwelijks waarnemers deel aan de waarnemingsmissies. Het oordeel van de verkiezingen door de OVSE werd echter steeds belangrijker - vooral in de Kaukasus met de rozenrevolutie in Georgië in 2003 en de oranjerevolutie eind 2004 in de Oekraïne.

De waarnemers zijn inmiddels afkomstig uit meer dan 40 OVSE-lidstaten, waaronder ook velen uit Rusland. Zij gaan, zoals gezegd, in tweetallen op pad. De teams bestaan bij voorkeur uit waarnemers uit verschillende landen en uit een ervaren en een minder ervaren waarnemer. $\mathrm{Zij}$ zullen het samen eens moeten worden over de onregelmatigheden die zij constateren. Slechts sporadisch komt het voor dat dit niet gebeurt.

Waarnemers kunnen ook fouten maken bij het beantwoorden van de vragen, en ook bij het invoeren van de gegevens kunnen fouten worden gemaakt. De ervaring leert echter dat dit maar zelden gebeurt.

Gelet op het voorgaande mogen we dus verwachten dat de bevindingen van de waarnemers adequaat weergegeven worden in de OVSE-rapporten. Toch is dat lang niet altijd zo. Over de vertaling van de bevindingen van de waarnemers in het voorlopige rapport beslist niet alleen de waarnemingsmissie van de OVSE. Er zijn nog andere partijen die mede het eindoordeel over het verkiezingsproces bepalen. Dat is de Europese Unie, die een aantal parlementsleden als waarnemers stuurt. Dat is meestal ook de Raad van Europa, die met enkele waarnemers vertegenwoordigd is. In sommige gevallen is dat een delegatie van de NAVO. En dan is er nog de parlementaire vertegenwoordiging van de OVSE. Op de ochtend na de verkiezingsdag komen alle delegaties bij elkaar. Mede op basis van het onderzoeksrapport over de bevindingen van de waarnemers, wordt de persverklaring opgesteld. De verklaring is uiteindelijk een compromis dat naar mijn mening vaak een te rooskleurig beeld geeft van de werkelijkheid. 


\section{Afgekeurde stemlokalen}

Het is goed om te beseffen dat de geobserveerde problemen en schendingen het topje zijn van een ijsberg. De echte fraude zal buiten het oog van de waarnemer plaatsvinden. Dat geldt vooral voor het stemproces omdat waarnemers maar zo'n 30 minuten in een stemlokaal aanwezig zijn.

Gemiddeld wordt per verkiezing 8 procent van de stemlokalen afgekeurd op basis van het stemproces. De meeste afkeuringen - 24 procent - vonden plaats in Azerbeidzjan in 2000 en 2004. Ook in Macedonië, Georgië en Tadzjikistan is het stemproces door veel waarnemers afgekeurd.

Het oordeel over het tellen van de stemmen is negatiever. Dat komt ook door de permanente aanwezigheid van de teams die het tellen bijwonen. Gemiddeld wordt 21 procent van de tellingen afgekeurd. In Wit-Rusland, Azerbeidzjan en Tadzjikistan was dat in de laatste jaren zelfs de helft.

$\mathrm{Er}$ is een duidelijke samenhang tussen het oordeel over het stemmen en het oordeel over het tellen van de stemmen. Waarnemers die veel problematische stemlokalen bezoeken bij het stemmen, constateren ook vaak dat het tellen van de stemmen niet vlekkeloos verloopt. Dit kunnen we aflezen aan de grafiek. Daarin is het percentage afgekeurde stemlokalen bij het stemproces afgezet tegen het percentage afkeuringen bij het tellen van de stemmen. De verklaarde variantie van 35 procent neemt toe tot 53 procent als de drie missies in WitRusland - waar veel waarnemers op een afstand werden gehouden bij het tellen niet worden meegenomen.

Grafiek 1. Afgekeurde stemlokalen 1996-2008 bij het stemproces en bij het tellen van de stemmen bij 73 verkiezingen.

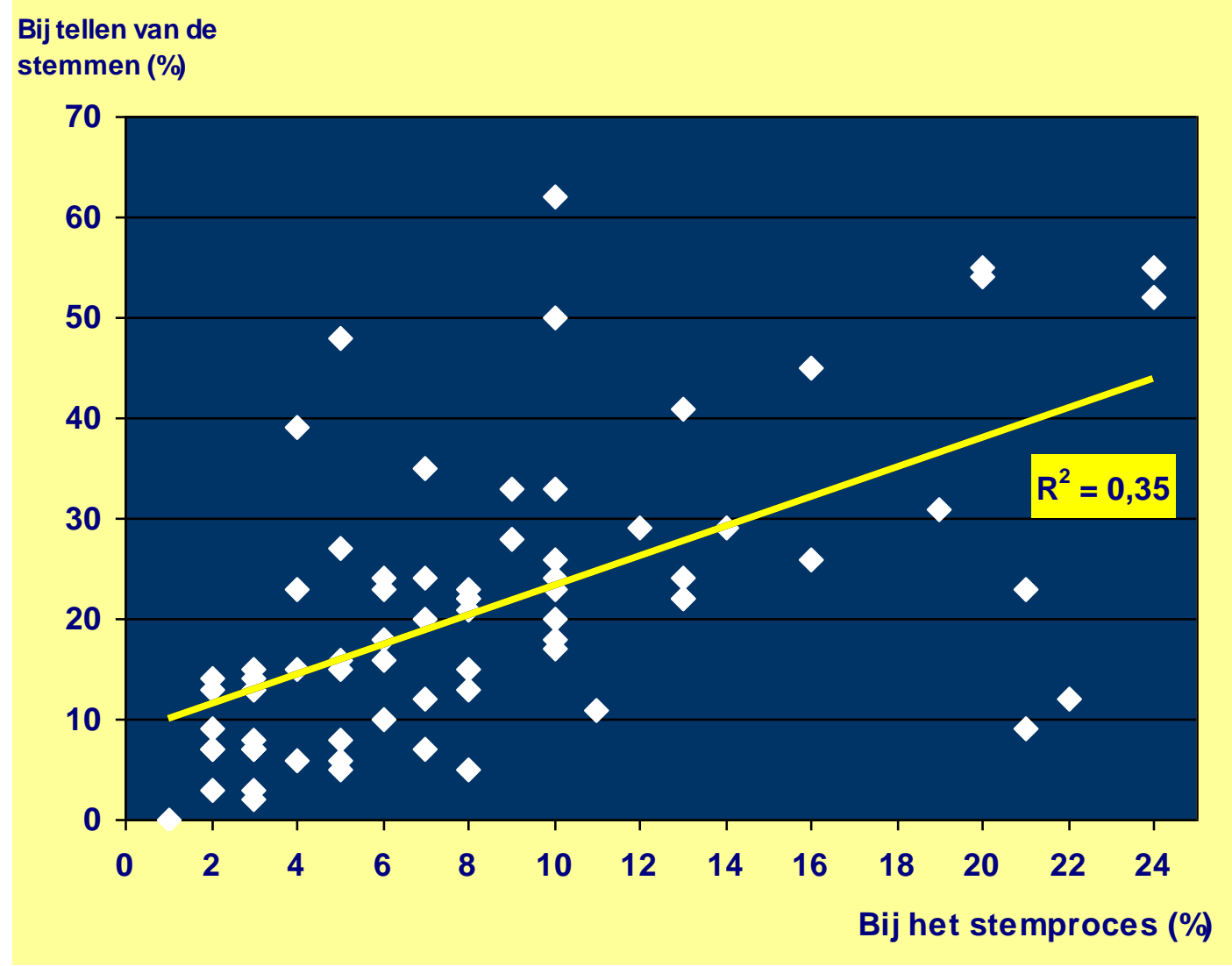


De statistieken vertellen ons nog meer. De laatste jaren verschuift de problematiek naar het tellen van de stemmen. Het eindoordeel daarover wordt steeds negatiever. Dit geldt niet voor het stemproces: het percentage afgekeurde stemlokalen neemt eerder af dan toe. Dit betekent dat de discrepantie tussen het oordeel over het stem- en telproces in de afgelopen twaalf jaar fors is toegenomen, van zo'n 5 procent in 1996 tot 20 procent in 2008.

Grafiek 2. Afgekeurde stemlokalen 1996-2008: Bij het stemmen (gele punten en lijn) en bij het tellen van de stemmen (blauwe punten en lijn).

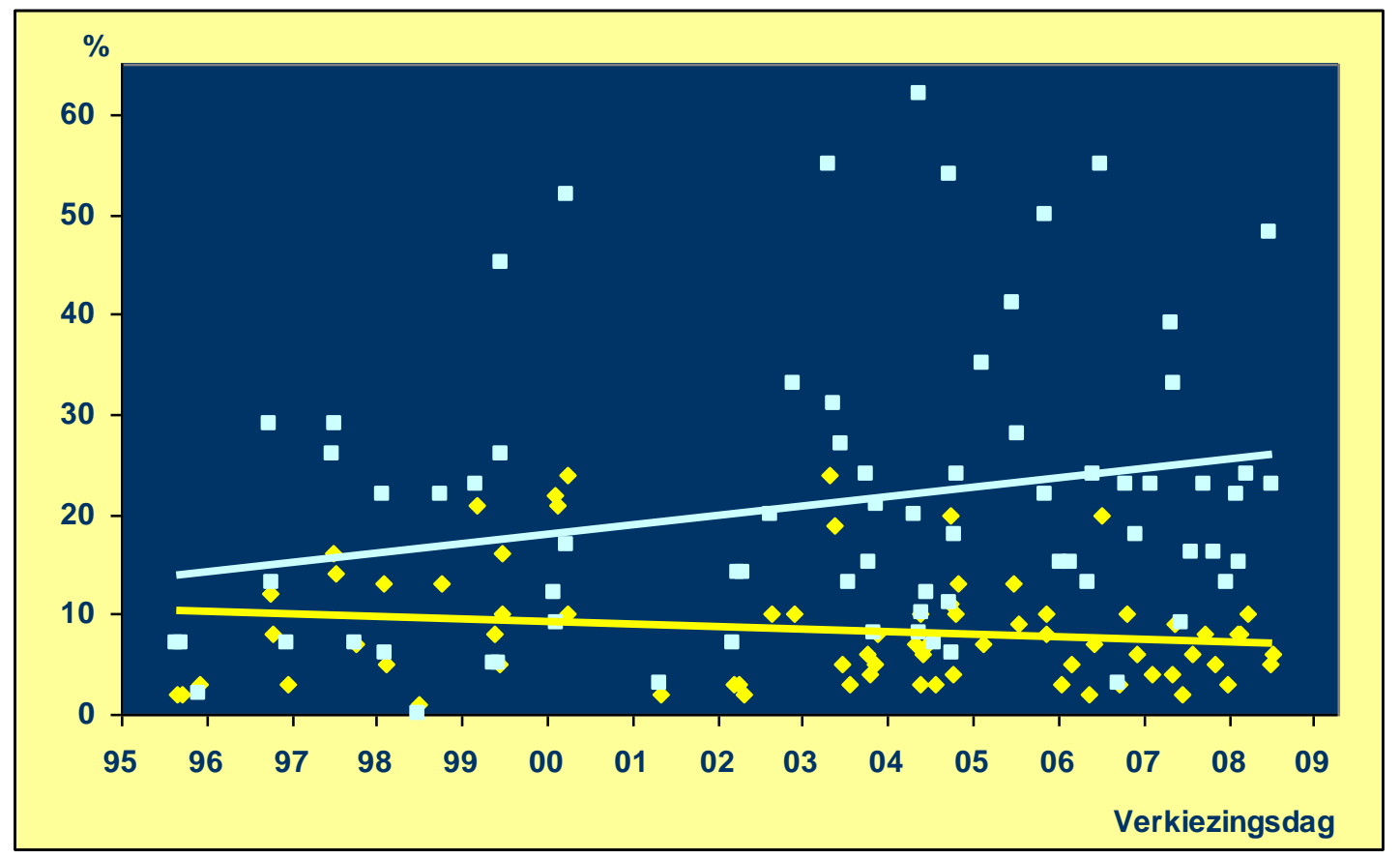

Ik kom nu tot een eindoordeel over het vertrouwen in het beoordelen van verkiezingen. Het feit dat de fouten van de waarnemers en bij het verwerken van de gegevens beperkt zijn, geeft vertrouwen in het grondmateriaal. De invloed van andere delegaties op de OVSE-verklaringen is enigszins problematisch. Ook het kortstondige verblijf van de waarnemers in de stemlokalen bij het stemmen, is discutabel. De sterke variatie in het aantal waarnemers dat wordt ingezet bij de verkiezingen is eveneens een zwak punt. Daardoor is in kleine missies het aantal observaties bij het tellen van de stemmen erg beperkt.

Mede gelet op het feit dat het tellen van de stemmen steeds vaker afgekeurd wordt, zou volgens mij het aantal in te zetten waarnemers, sterker dan nu, gestandaardiseerd moeten worden. Ik zou willen pleiten voor zo'n 600 waarnemers, dus 300 teams. Dit aantal biedt het voordeel dat er ook permanente teams voor het observeren van het stemproces ingezet kunnen worden. Tevens zal dan het aantal observaties voor de openingsprocedures en het tellen van de stemmen telkens zo'n 300 zijn. Daardoor is gegarandeerd dat de uitspraken over deze fasen van het verkiezingsproces gebaseerd zijn op een substantieel aantal observaties, hetgeen het vertrouwen in de OVSE-verklaringen ten goede komt. En dat is gunstig voor het vertrouwen in uitspraken over het hart van de democratie: de verkiezingen. 


\section{Sociale Samenhang en het Sociaal Statistisch Bestand}

Aan het begin van mijn betoog ben ik ingegaan op de opdracht van mijn leerstoel, waarin ik aandacht zal geven aan de empirische beschrijving van sociale samenhang. Onderzoek naar de politieke participatie, waaronder het stemgedrag, krijgt daarin een plek. Deze activiteiten passen binnen het nieuwe speerpunt Sociale Samenhang van het CBS dat ik - samen met anderen - de komende vier jaar zal uitvoeren.

Onderzoek naar sociale samenhang richt zich doorgaans op de deelname van de burgers aan activiteiten op drie niveaus: (1) informele sociale contacten; (2) participatie in organisaties; en (3) politieke participatie.

Maar sociale samenhang is meer dan alleen de mate waarin mensen participeren in de samenleving. Het gaat ook om de kwaliteit van die activiteiten. Het onderlinge vertrouwen, het vertrouwen in organisaties en het vertrouwen in de politiek zijn essentieel. Naast participatie en vertrouwen is het vraagstuk van de integratie van belang. Het gaat niet alleen om het contact en vertrouwen binnen de bevolkingsgroepen, maar ook om het contact en vertrouwen tussen deze groepen. Deze drie dimensies - de participatie, het vertrouwen en de integratie vormen het raamwerk van de sociale samenhang.

Een raamwerk is niet voldoende voor de empirische beschrijving van de sociale samenhang. Een hiaat in nationaal en internationaal onderzoek is een gebrek aan studies waarin deze dimensies in hun onderlinge samenhang worden onderzocht. Het Sociaal Statistisch Bestand van het CBS biedt meer mogelijkheden om de sociale samenhang integraal te bepalen. Zo zijn van de gehele bevolking de sociaal-demografische gegevens, zoals het geslacht, leeftijd, etniciteit, en adres, bekend. Aan deze data worden andere registraties toegevoegd: fiscale gegevens om het besteedbare inkomen vast te stellen, gegevens over uitkeringen, en de aard van het dienstverband. Bepaald wordt wat de kenmerken zijn van de buurt en wijk waar iemand woont, zoals de etnische samenstelling en de WOZ-waarde van de woningen.

Aan deze gegevens zijn de steekproefonderzoeken gekoppeld, waaronder de doorlopende enquêtes over de arbeidsmarkt, de leefsituatie en veiligheid, en de incidentele enquêtes over gezinsvorming, het stemgedrag en integratie. Op basis van dit immense bestand zijn talloze onderzoeksvragen naar de sociale samenhang te beantwoorden.

Ik geef een voorbeeld om te laten zien welke mogelijkheden dit bestand biedt. In de Veiligheidsmonitor is aan 52 duizend personen gevraagd naar de betrokkenheid in de buurt in de periode 2005-2008. We kunnen kijken naar de verdelingen en constateren dat deze betrokkenheid licht is toegenomen (zie Tabel 2).

Daarnaast is er regionale informatie beschikbaar, zoals de concentratie nietwesterse allochtonen in gemeenten en buurten. Nu kunnen we nagaan of de betrokkenheid in de buurt gerelateerd is aan de etnische samenstelling. Het percentage niet-westerse allochtonen varieert van 1 procent in de gemeenten zoals Aalburg en Boekel tot 32 procent in Den Haag, 33 procent in Amsterdam en 34 procent in Rotterdam. Ook hebben we gemiddelde betrokkenheid bij de buurt per gemeente vastgesteld. Op basis van een optelsom van de acht stellingen kan 
deze betrokkenheid variëren van 0 (geen enkele betrokkenheid) tot 32 (maximale betrokkenheid). De gemiddelde score van de gemeenten ligt tussen 18 en 27 in. Gemeenten met een hoge concentratie niet-westerse allochtonen scoren duidelijk lager op de gemiddelde betrokkenheid.

Tabel 2. Sociale betrokkenheid in de buurt, \% (helemaal) mee eens, 2005-2008

\begin{tabular}{|lllll|}
\hline & 2005 & 2006 & 2007 & 2008 \\
\hline Veel contact met directe buren & & & & \\
\hline Veel contact met andere buurtbewoners & $\mathbf{6 2}$ & 64 & 65 & $\mathbf{6 5}$ \\
\hline Men gaat op een prettige manier met elkaar om & $\mathbf{4 5}$ & 47 & 48 & $\mathbf{4 8}$ \\
\hline Gezellige buurt met veel saamhorigheid & 59 & 58 & 85 & $\mathbf{8 6}$ \\
\hline Mensen kennen elkaar nauwelijks & 21 & 21 & 20 & 20 \\
\hline Thuis voelen bij de mensen in de buurt & 77 & 77 & 78 & 79 \\
\hline Als enigszins mogelijk, verhuis ik uit deze buurt & 12 & 12 & 12 & 12 \\
\hline Tevreden met de bevolkingssamenstelling & 84 & 85 & 85 & 85 \\
\hline
\end{tabular}

\section{Betrokkenheid in buurt per gemeente, naar}

$\%$ niet-westerse allochtonen, 2005-2008

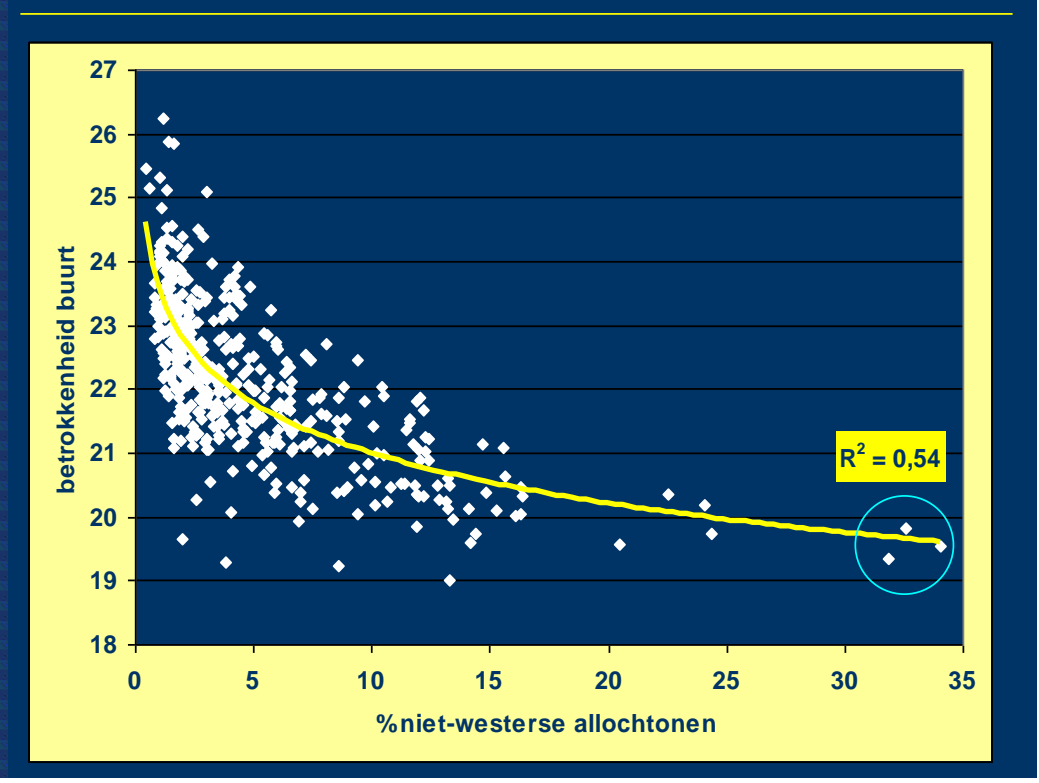

Hoe kunnen we deze sterke samenhang interpreteren? Zijn misschien andere kenmerken van de gemeente van belang om de buurtbetrokkenheid vast te stellen? Is bijvoorbeeld de sociale samenhang in de buurt lager in sociaaleconomische zwakke buurten, waar ook veel niet-westerse allochtonen wonen? Armoede en een perceptie van onveiligheid in specifieke buurten zouden dan leiden tot een groter wantrouwen, tot minder contacten en tot minder tevredenheid met de woonbuurt. 
De bevolkingssamenstelling kan ook debet zijn aan variatie in buurtbetrokkenheid tussen de gemeenten. Als bijvoorbeeld niet-westerse allochtonen een negatiever oordeel hebben over de buurt, dan is het niet vreemd dat in gemeenten met hoge concentraties niet-westerse allochtonen de buurtbetrokkenheid geringer is.

Het effect van de concentratie niet-westerse allochtonen op de buurtbetrokkenheid wordt echter nauwelijks aangetast indien rekening wordt gehouden met zowel een groot aantal buurtkenmerken als met de samenstelling van de bevolking. De sociale betrokkenheid in de buurt neemt duidelijk toe indien de buurt minder gekleurd is. Binnen de opdracht van mijn leerstoel zal ik, met het Sociaal Statistisch Bestand, de effecten van buurtkenmerken op de sociale samenhang bestuderen.

\section{Tot slot}

Ik ga afronden. Vertrouwen van de kiezer in het verkiezingsproces is een cruciaal aspect bij verkiezingen. Vertrouwen in de bevindingen van de waarnemers is van belang om verkiezingen te beoordelen. En vertrouwen in de sociale statistiek is essentieel om de sociale samenhang te onderzoeken.

Ik heb enkele mogelijkheden aangestipt om met het Sociaal Statistisch Bestand de empirische bestudering van sociale samenhang vorm te geven. Binnen het onderwijs- en onderzoeksprogramma van de faculteit Cultuur- en Maatschappijwetenschappen zal ik mij in de komende vier jaar bezig gaan houden met de integrale bestudering van de drie dimensies van sociale samenhang: participatie, vertrouwen en integratie.

Mijn leven zal zich meer dan voorheen afspelen rondom studenten. Het studentenleven vindt niet alleen plaats op de universiteit, maar voor velen ook in de kroeg. Daar is niets op tegen. Sterker nog, het met elkaar babbelen, heeft zeker zijn voordelen. Dit schmoezen, zoals Robert Putnam het zo treffend in zijn boek Bowling alone uitdrukt, is gunstig voor vele facetten van het leven, zoals de gezondheid, en het ervaren geluk. Sommige studenten zetten dit schmoezen meteen in klinkende munt om door in de horeca te werken. Werken kan echter ook bij het CBS. Inmiddels is een aantal studenten hiermee gestart.

Ook op andere terreinen zal ik de samenwerking tussen het CBS en de universiteit van Maastricht trachten te stimuleren. Zo is binnen het op te starten 2-jarige Researchmaster European Studies een aantal bezoeken aan het CBS ingepland. Voorts wordt door de universiteit meer gebruik gemaakt van de rijke databestanden van het CBS en de expertise op het gebied van de sociale statistiek voor het onderwijs en onderzoek.

Professor Leeuw heeft ons in zijn oratie op 23 mei verleden jaar gewezen op twee beginnersfouten. In een oratie moet je niet teveel ingaan op wat je allemaal van plan bent te gaan doen. De tweede beginnersfout is om een uitgebreid dankwoord op te nemen. Ik besef dus dat ik - door Frans Leeuw te bedanken die naast Peer Scheepers mij adviseerde over de te nemen stappen op weg naar de bijzondere leerstoel - voor altijd te boek zal staan als die beginneling. En voor het geval daar iemand achteraf nog over zou kunnen twijfelen, zal ik nog even doorgaan met bedanken. Op de eerste plaats mijn vriendin en vrouw - ik gebruik dat door 
elkaar - Jeanet. Zonder haar hulp, geduld, en vooral vertrouwen, zou ik hier niet staan.

Aan het CBS heb ik veel te danken, een prachtige werkgever, heel veel leuke collega's, met een corps interviewers dat we moeten koesteren. De stuwende, en vooral stille, kracht om de leerstoel in te stellen binnen een convenant tussen de Universiteit van Maastricht en het CBS is Wim de Witte. Niet alleen daarom zou het gepast zijn om te spreken van 'De Witte Leerstoel', in plaats te proberen om Sociale Statistiek (SS) of Sociale Samenhang (SS) af te korten.

Ten slotte spreek ik mijn dank uit voor het vertrouwen dat de directie van het CBS, het College van Bestuur van de Universiteit van Maastricht, de decaan en medewerkers van de faculteit cultuur- en maatschappijwetenschappen, en in het bijzonder de capaciteitsgroep Politieke Wetenschap, in mij heeft gesteld.

Ik werk nu één dag per week in Maastricht, zo'n 100 meter van ons huis. Opgegroeid ben ik echter in hotel café restaurant 'De Poort', gelegen aan de rijksweg op nummer 66 te Lemiers. Nu wil het toeval dat mijn werkplek pal tegenover een ander café met de naam 'De Poort' ligt. Ruim zes jaar geleden verdedigde ik in mijn proefschrift onder andere de stelling 'Indien Maastricht het balkon van Europa is, dan moeten de fundamenten in Lemiers liggen'. Dat ik met deze stelling nu weer geconfronteerd word, schept niet alleen verbazing, maar ook vertrouwen.

Ik heb gezegd. 